\title{
Coronal pulp cavity index as noble modality for age estimation: a digital image analysis
}

Kusum Singal ${ }^{1}$, Neelkamal Sharma ${ }^{1 *}$, Vikas Kumar $^{1}$ and Permila Singh ${ }^{2}$

\begin{abstract}
Background: In the field of forensic dentistry, various radiographic techniques have been used for age estimation. The coronal pulp cavity index $(\mathrm{CPCl})$ indicates a reduction in the pulp chamber with age as a result of secondary dentin deposition.

Methods: The study was conducted on 416 radiovisiographs (RVGs) with the aim to correlate CPCI with chronological age. Digital dental radiographs of four teeth from every subject were taken after written consent. Teeth selected for RVGs in the present study were maxillary canine, maxillary second premolar, mandibular canine, and mandibular first premolar. Two linear measurements were taken for each tooth: one was the tooth crown height $(\mathrm{CH})$ and the second was the coronal pulp height $(\mathrm{CPH})$. Coronal pulp cavity index was calculated for each tooth.
\end{abstract}

Results: Data was statistically analyzed. ANOVA was used to show the strength of the relation between $\mathrm{CPCl}$ and chronological age. This study represents the first pilot investigation of this method in a Haryana population. A strong negative linear relationship was found between $\mathrm{CPCl}$ and chronological age.

Conclusion: Age of an individual can be estimated with a good degree of accuracy using population and sexspecific regression equations. The maxillary second premolar was reported as the most reliable indicator of age in both males as well as females.

Keywords: Forensic dentistry, Coronal pulp cavity index (CPCl), Digital dental radiographs, Radiovisiographs, Age estimation, Radiographic method, Dentine deposition, Age biomarker

\section{Background}

Individualization of a person is a key goal in forensic science. Besides sex, age is the fundamental biological parameter which permits individualization of human remains (Koranne et al., 2017). Forensic age estimation may be many times necessary in living persons in criminal and civil cases when the individual is either unwilling or unable to reveal his identity (Lewis and Senn 2010; Rai et al. 2010). Most systems for age estimation rely on the bones and teeth (Ferenandes et al. 2011). These different methods offer prevalent outcomes (Ge et al. 2015, 2016). But when these strategies are assessed

\footnotetext{
* Correspondence: neelforensics@gmail.com

'Department of Genetics, MDU Rohtak, Rohtak, India

Full list of author information is available at the end of the article
}

independently, those strategies that employ dental evidence offer more reliable and precise results for discovering age (Cheena and Kusum, 2017).

In some crime scenes or archaeological digs, the teeth may be the only thing left as the teeth are preserved for a longer period of time than other body tissue and thus can be used for accurate age estimation in heavily decayed corpses (Singal and Sharma 2017). The teeth comprise enamel (the outermost covering of the crown), dentin, and cementum (the outermost covering of the root) which makes them nearly less susceptible to environmental destruction (Talabani et al., 2015; Porto et al., 2015; Ge et al. 2016). In forensic literature, several authors have detailed a variety of procedures for dental age computation such as biochemical, histological, morphological, and radiological techniques 


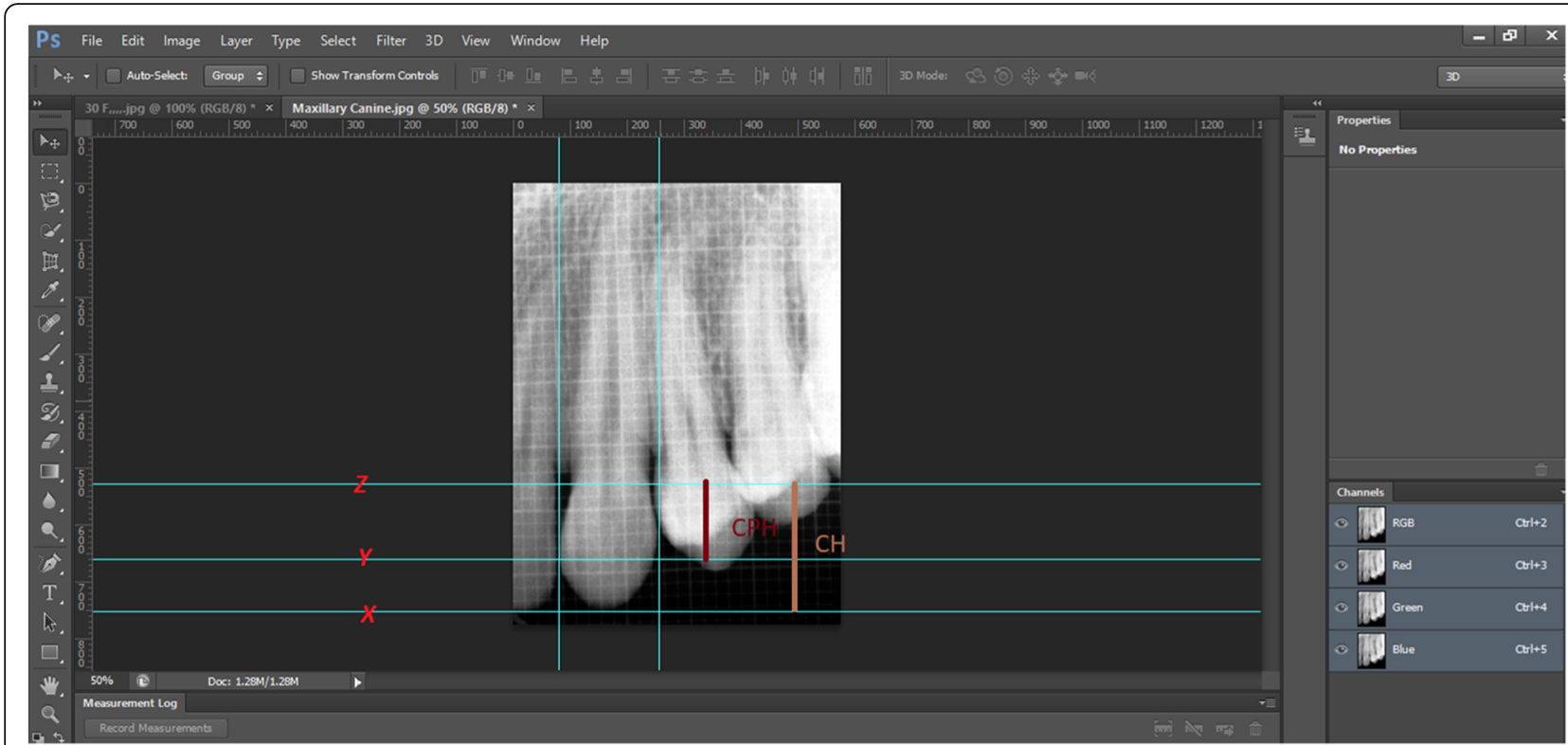

Fig. 1 Showing measurements on maxillary canine (between two vertical lines) using Adobe Photoshop ( $X, Y$, and $Z$ are the horizontal reference lines, CPH coronal pulp height and CH coronal height)

(Someda et al. 2009; Joseph et al., 2013; Takasaki et al. 2003; Shrestha 2014).

Morphological methods are subjective in nature and predict a wider range of age. Biochemical and histological methods are destructive strategies which demand extraction of the teeth and so are unethical and not always possible in the case of living individuals (Jagannathan et al. 2011; Singal 2017). This leaves only radiographic methods, which are non-destructive, practical, and applicable for estimating the ages of living people who have completely developed teeth (Babshet et al. 2010). The radiographic technique utilizes different parameters for age estimation including secondary dentin statement (Panchbhai 2011). Dentin is released by the odontoblastic processes throughout the life of an individual (Das et al., 2017). Continuous deposition of dentin will lead to a decrease in the size of the pulp cavity. Thus, the size of the dentine deposition is a useful age biomarker. The literature reports different radiological techniques for age assessment (Talabani et al. 2015; Pushpa et al. 2017; Koranne et al. 2017).

Table 1 Age and gender distribution of study subject

\begin{tabular}{llll}
\hline Age groups (years) & Males $(n)$ & Females $(n)$ & Total \\
\hline $15-24$ & 10 & 10 & 20 \\
$25-34$ & 13 & 13 & 26 \\
$35-44$ & 15 & 15 & 30 \\
$45-54$ & 14 & 14 & 28 \\
\hline
\end{tabular}

The present study was undertaken in the Department of Genetics (Forensic Science), Maharshi Dayanand University (MDU), Rohtak, Haryana, with a plan to quantify tooth-coronal index (CPCI) on radiovisiographs (RVG) of various teeth (maxillary canine, maxillary second premolar, mandibular canine, and mandibular first premolar) using digital image software and to derive population-specific and sex-oriented regression equations for age estimation.

\section{Methodology}

\section{Subjects and materials}

The study sample consists of radiovisiographs of 416 intact teeth (104 maxillary canines, 104 maxillary second premolars, 104 mandibular canines, and 104 mandibular first premolars) of the left side. Radiographs were collected from 104 individuals (52 males and 52 females) of known sex and age who has visited Post Graduate Institute of Dental Sciences (PGIDS), Rohtak, and PDM Dental College \& Research Institute, Bahadurgarh, for the routine dental check-up during a period of 1 year (July 2017 to July 2018).

\section{Inclusion and exclusion criteria}

Only monoradicular teeth were included in the study. Canines (both maxillary as well as mandibular) and premolars (maxillary second premolar and mandibular first premolar) were selected for the study. These particular teeth have less chance for 


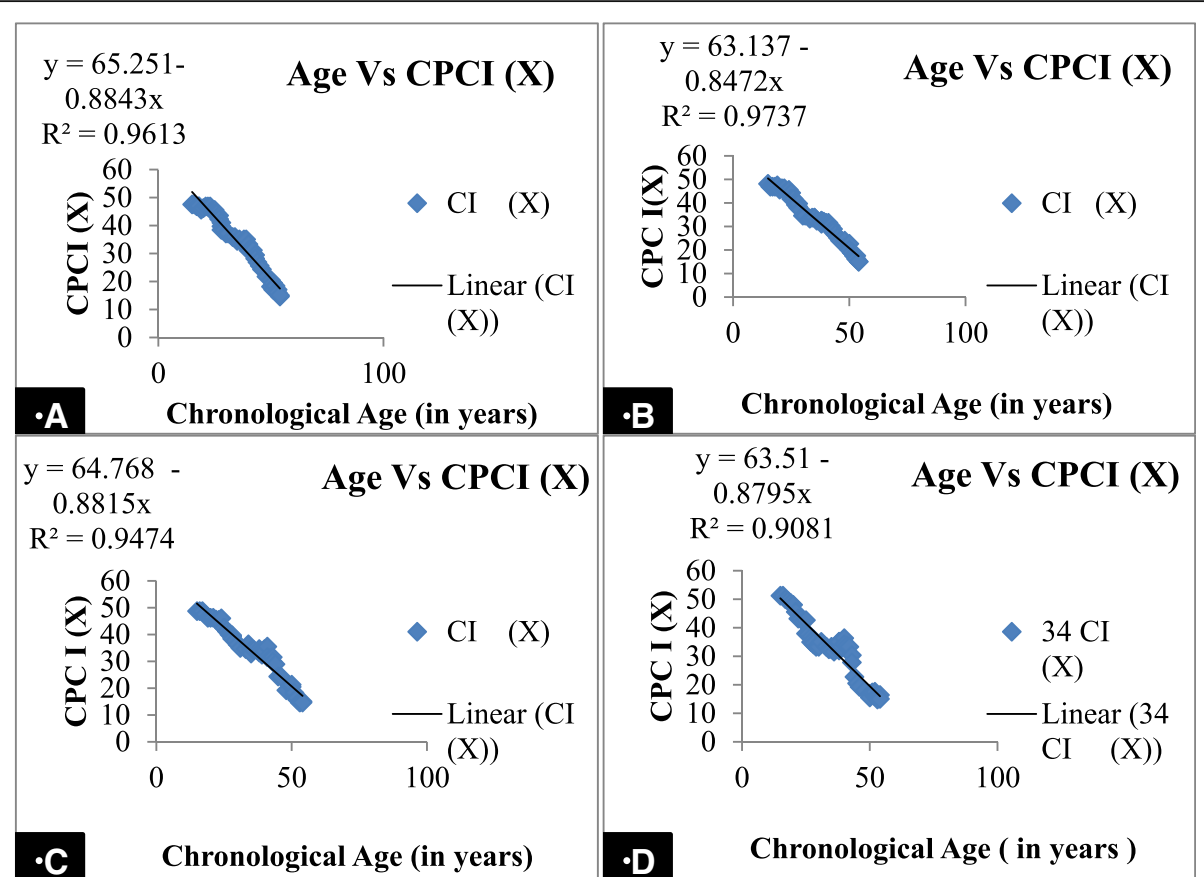

Fig. 2 Regression equation of maxillary canine (a), maxillary second premolar (b), mandibular canine (c), and mandibular first premolar (d) for male study samples ( $Y$ represents the estimated age, $X$ is the coronal index, and $R^{2}$ indicates the regression coefficient)

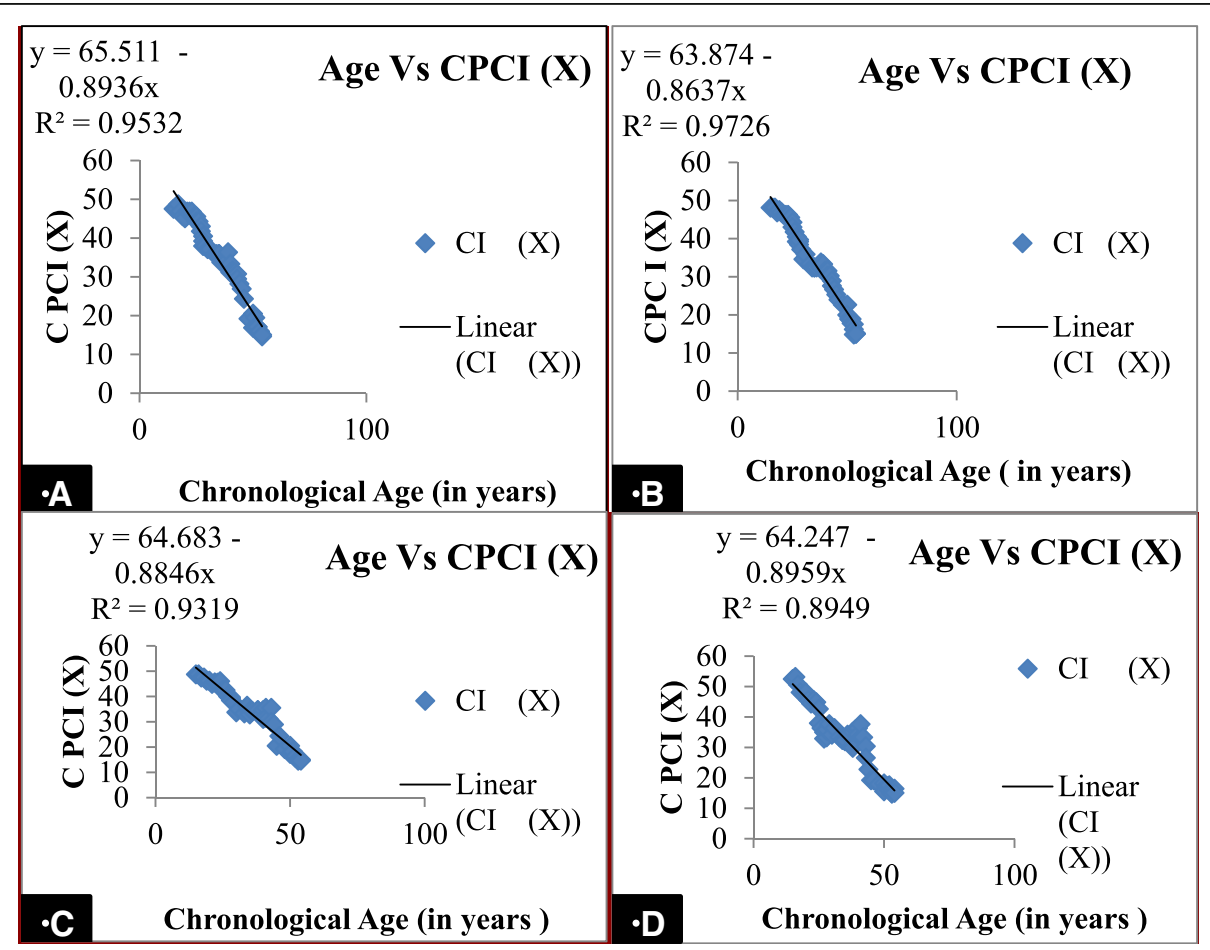

Fig. 3 Regression equation of maxillary canine (a), maxillary second premolar (b), mandibular canine (c), and mandibular first premolar (d) for female study samples ( $Y$ represents the estimated age, $X$ is the coronal index, and $R^{2}$ indicates the regression coefficient) 
Table 2 Showing regression equations along with their regression coefficients between age and $\mathrm{CPCl}$ by gender and teeth type

\begin{tabular}{lll}
\hline Teeth & Males & Females \\
\hline Maxillary canine & $Y=65.251-0.8843 \times\left(R^{2}\right.$ & $Y=65.511-0.8936 \times\left(R^{2}\right.$ \\
& $=96.1)$ & $=95.3)$ \\
Maxillary second & $Y=63.137-0.8472 \times$ & $Y=63.874-0.8637 \times\left(R^{2}\right.$ \\
premolar & $\left(R^{2}=97.4\right)$ & $=97.3)$ \\
Mandibular canine & $Y=64.768-0.8815 \times\left(R^{2}\right.$ & $Y=64.683-0.8846 \times\left(R^{2}\right.$ \\
& $=94.7)$ & $=93.1)$ \\
Mandibular first & $Y=63.51-0.8795 \times\left(R^{2}\right.$ & $Y=64.247-0.8959 \times\left(R^{2}\right.$ \\
premolar & $=90.8)$ & $=89.4)$
\end{tabular}

$Y$ indicates estimated age while $X$ represents $\mathrm{CPCl} . R^{2}$ indicates regression coefficients

wear than other anterior teeth, are frequently present in older age groups, have the largest pulp area in the case of canines, and are least affected by masticatory action. Radiovisiographs of the subjects were taken after a written consent was signed by the subjects. The ages of the individuals ranged from 15 to 54 years. Radiographic machine (Gnatus X-ray machine having specification $70 \mathrm{kV} / 7 \mathrm{~mA}, 0.05 \mathrm{~s}$ exposure; Kodak RVG 5200 Digital X-ray dental sensor; and XCP-DS Digital Sensor Holders) was used in the present study. For standardization of radiographs, film holder mounted on an occlusal splint and connected to the X-ray tube was used. All the RVGs were taken using the paralleling technique using grid.

RVG was chosen as a mode of imaging because it has the following advantages: (1) cutting of the teeth is not necessary, (2) radiation exposure to the subject is less than from other methods, (3) RVGs can be stored in the computer for later use, (4) less time is taken as no manual processing of radiographs is required, and (5) clarity is very good for assessing the pulp chamber as well as other details of the teeth. Subjects with any developmental, endocrine or nutritional disorder, or special dental problems like impacted teeth, teeth with root canal treatment, crown restorations, broken teeth, teeth with large areas of enamel overlap between neighboring teeth, missing teeth, or unclear radiographs were excluded from the study. To overcome the magnification and angulation differences, a grid was used while taking the RVG of each tooth. Protocol
Table 4 ANOVA of maxillary second premolar for male study samples

\begin{tabular}{lllllll}
\hline & Coefficients & $\begin{array}{l}\text { Standard } \\
\text { error }\end{array}$ & $t$ Stat & $\begin{array}{l}P \\
\text { value }\end{array}$ & $\begin{array}{l}\text { Lower } \\
95 \%\end{array}$ & $\begin{array}{l}\text { Upper } \\
95 \%\end{array}$ \\
\hline Intercept & 63.13719 & 0.745417 & 84.70048 & $1.14 \mathrm{E}$ & 61.63998 & 64.6344 \\
& & & & -55 & & \\
CI (X) & -0.8472 & 0.019701 & - & $3.68 \mathrm{E}$ & - & - \\
& & & 43.0021 & -41 & 0.88677 & 0.80763 \\
\end{tabular}

of the study was approved by the Institutional $\mathrm{Hu}$ man Ethical Committee, MDU Rohtak (ethical clearance dated on July 4, 2017).

\section{Radiographic measurements}

Every radiographic image was recorded as a computer file, which was processed using a computeraided imaging program. The following measurements (in millimeter) were taken independently on every RVG, one was crown height and the other was coronal pulp height. Then, CPCI for each tooth was calculated as follows: $\mathrm{CPCI}=\mathrm{CPH} \times 100 / \mathrm{CH}$. Three reference points were used in the present study for measuring CPCI. One is the cervical line, the second is the height of the crown, and the third is the height of the coronal pulp cavity (Fig. 1). To prevent or minimize intraobserver errors, all measurements were carried out twice after an interval of 2 weeks by the same observer. Intraobserver reproducibility and reliability (99.96\%) of measurements was studied using the concordance correlation coefficient $(P<0.05)$. Intraobserver reliability of measurement for $\mathrm{CPH}, \mathrm{CH}$, and $\mathrm{CPCI}$ was 99.95\%, 99.96\%, and 99.96\%, respectively.

\section{Statistical analysis}

The chronological age of each tooth was calculated as the difference between the date of birth and the date on which the RVG was taken. The data obtained were tabulated, sorted in an Excel file, and statistically analyzed. Simple regression analysis was carried out for each tooth using Microsoft Excel package for Windows 2010 to derive regression equations for age estimation. The results were calculated and correlated with the chronologic age for evaluation. ANOVA (analysis of variance) was done to compare mean chronological age and mean

Table 3 ANOVA of maxillary canine for male study samples

\begin{tabular}{lllllll}
\hline & Coefficients & Standard error & $t$ Stat & $P$ value & Lower 95\% & Upper 95\% \\
\hline Intercept & 65.25116122 & 0.949297084 & 68.73629 & $3.57 \mathrm{E}-51$ & 63.34444 & 67.15 \\
CI (X) & 0.884328912 & 0.02508983 & -35.2465 & $5.6 \mathrm{E}-37$ & -0.93472 & -0.83393 \\
\hline
\end{tabular}


Table 5 ANOVA of mandibular canine for male study samples

\begin{tabular}{|c|c|c|c|c|c|c|}
\hline & Coefficients & $\begin{array}{l}\text { Standard } \\
\text { error }\end{array}$ & $t$ Stat & $\begin{array}{l}P \\
\text { value }\end{array}$ & $\begin{array}{l}\text { Lower } \\
95 \%\end{array}$ & $\begin{array}{l}\text { Upper } \\
95 \%\end{array}$ \\
\hline ot & 64.76816 & 1.111084 & 58.29275 & $\begin{array}{l}1.23 \mathrm{E} \\
-47\end{array}$ & 62.53648 & 66.99 \\
\hline$(X)$ & -0.88149 & 0.029366 & $\begin{array}{l}- \\
30.0175\end{array}$ & $\begin{array}{l}1.2 \mathrm{E} \\
-33\end{array}$ & $\begin{array}{l}- \\
0.94047\end{array}$ & $\begin{array}{l}- \\
0.82251\end{array}$ \\
\hline
\end{tabular}

estimated age by CPCI. The significance threshold was set at $5 \%$. The prediction equations for predicting the age using CPCI for each tooth was calculated using regression analysis.

\section{Results}

The following results were obtained from RVGs of 416 teeth of 104 subjects having the age range 1554 years (Table 1). Statistical analysis for the whole sample was done by ANOVA and regression analysis. ANOVA was used to show the relation strength between age and CPCI. Regression equations were derived for age estimation utilizing CPCI. Coefficient of determination $\left(R^{2}\right)$ calculated ranges from 0.894 to 0.973 [Figs. 2 and 3]. Significant $F$ and $P$ values suggest the reliability of results ( $F$ and $P$ significant values are less than 0.05). In regression equations, $Y$ represents the age which is to be estimated and $X$ is the dependent variable CPCI. $R^{2}$ indicates the percentage of variation explained by the independent variable CPCI (Table 3). Each study subset has an equal number of observations. Standard error ranges from 1.66 to 3.33 in males and from 1.76 to 3.66 in females, respectively. ANOVA and regression analysis by sex and tooth type was done (Tables $3,4,5,6,7$, 8,9 , and 10]. High significant $P$ value $(P<0.05)$ has been reported in all study subsets. Analysis has been done to compare the difference between chronological age and mean estimated age in test subset for each tooth group. Highly significant $P$ value was reported in all the teeth (Tables 11, 12, 13, and 14). For males, its values vary from 0.29 to 0.50 and for females from 0.28 to 0.44 , respectively.

\section{Discussion}

Age estimation is a vital step in the identification of unknown. If the age can be precisely evaluated, it

Table 6 ANOVA of mandibular first premolar for male study samples

\begin{tabular}{lllllll}
\hline & Coefficients & $\begin{array}{l}\text { Standard } \\
\text { error }\end{array}$ & $t$ Stat & $\begin{array}{l}P \\
\text { value }\end{array}$ & $\begin{array}{l}\text { Lower } \\
95 \%\end{array}$ & $\begin{array}{l}\text { Upper } \\
95 \%\end{array}$ \\
\hline Intercept & 63.51038 & 1.497492 & 42.41116 & $7.22 \mathrm{E}$ & 60.50258 & 66.51818 \\
& & & & -41 & & \\
$\mathrm{Cl}(\mathrm{X})$ & -0.87951 & 0.039579 & - & $1.44 \mathrm{E}$ & -0.959 & - \\
& & & 22.2218 & -27 & & 0.80001 \\
\hline
\end{tabular}

Table 7 ANOVA of maxillary canine for female study samples

\begin{tabular}{lllllll}
\hline & Coefficients & $\begin{array}{l}\text { Standard } \\
\text { error }\end{array}$ & $t$ Stat & $\begin{array}{l}P \\
\text { value }\end{array}$ & $\begin{array}{l}\text { Lower } \\
95 \%\end{array}$ & $\begin{array}{l}\text { Upper } \\
95 \%\end{array}$ \\
\hline Intercept & 65.51104 & 1.058975 & 61.8627 & $6.53 \mathrm{E}$ & 63.38403 & 67.63806 \\
& & & & -49 & & \\
$\mathrm{Cl}(\mathrm{X})$ & -0.8936 & 0.027989 & - & $6.41 \mathrm{E}$ & - & - \\
& & & 31.9271 & -35 & 0.94981 & 0.83738 \\
\hline
\end{tabular}

will significantly limit the field of possible identities. These days, forensic odontologists are frequently stood up with various cases of age estimation in living as well as dead persons (Stavrianos et al. 2008). In living persons, the importance of a reliable tool for age estimation is quite significant as legal consequences are entirely unexpected if a subject of an unknown case is judged to be juvenile or an adult (Godge et al. 2014).

Different strategies have been developed in the field of forensic odontology for age estimation on the basis of different parameters using various teeth. Decrease in pulp size due to deposition of secondary dentine is considered to be one of the reliable biomarkers that can be used for age estimation (Mathew et al., 2013; Karkhanis et al., 2013). Tooth cross-sectioning and radiographs are the methods that can be used for measurement of secondary dentin deposition (Singaraju and Sharada, 2009). Digital radiographic measurements being non-destructive in nature are generally acknowledged to estimate the age of a person (Singaraju and Sharada 2009; Drusini et al. 1997).

The present study for age estimation was conducted utilizing 416 RVGs. The teeth incorporated in this examination were maxillary canine, maxillary second premolar, mandibular canine, and mandibular first premolar. Canines were chosen because of better anchorage, having the longest root and longlasting teeth in the oral cavity. Less influence of masticatory forces on premolars make them reasonable for use in the present study.

The sample was divided into four age groups (Table 1). Linear regression equations were derived for different teeth for males and females separately. Regression coefficients for different teeth extend from 0.90 to 0.97 among males and 0.89 to 0.97 in

Table 8 ANOVA of maxillary second premolar for female study samples

\begin{tabular}{|c|c|c|c|c|c|c|}
\hline & Coefficients & $\begin{array}{l}\text { Standard } \\
\text { error }\end{array}$ & $t$ Stat & $\begin{array}{l}P \\
\text { value }\end{array}$ & $\begin{array}{l}\text { Lower } \\
95 \%\end{array}$ & $\begin{array}{l}\text { Upper } \\
95 \%\end{array}$ \\
\hline Intercept & 63.87397 & 0.775686 & 82.34512 & $\begin{array}{l}4.62 E \\
-55\end{array}$ & 62.31595 & 65.43198 \\
\hline$C I(X)$ & -0.86371 & 0.020501 & $\begin{array}{l}- \\
42.1295\end{array}$ & $\begin{array}{l}9.99 E \\
-41\end{array}$ & $\begin{array}{l}- \\
0.90489\end{array}$ & $\begin{array}{l}- \\
0.82253\end{array}$ \\
\hline
\end{tabular}


Table 9 ANOVA of mandibular canine for female study samples

\begin{tabular}{lllllll}
\hline & Coefficients & $\begin{array}{l}\text { Standard } \\
\text { error }\end{array}$ & $t$ Stat & $\begin{array}{l}P \\
\text { value }\end{array}$ & $\begin{array}{l}\text { Lower } \\
95 \%\end{array}$ & $\begin{array}{l}\text { Upper } \\
95 \%\end{array}$ \\
\hline Intercept & 64.68309 & 1.279974 & 50.5347 & $1.38 \mathrm{E}$ & 62.11218 & 67.25399 \\
& & & & -44 & & \\
$\mathrm{Cl}(\mathrm{X})$ & -0.8846 & 0.03383 & - & $7.95 \mathrm{E}$ & - & - \\
& & & 26.1487 & -31 & 0.95255 & 0.81665 \\
\hline
\end{tabular}

female study subjects. The results of the present study suggests that CPCI of all the selected teeth demonstrated a strong negative correlation with chronological age which is in accordance with previous studies directed by Drusini, Ikeda et al., Paewinsky et al., and Igbigbi et al. (Drusini et al. 1997; Ikeda et al. 1985; Igbigbi and Nyirenda, 2005; Paewinsky et al. 2005).

No exceptionally huge impact of sex was accounted on age estimation using CPCI method; however, our study found the correlation of CPCI with age is higher in males than in females irrespective of the tooth type which is supported by the results of previous study conducted by Drusini (Table 2). Hormonal differences in males and females may be a reason for such variations suggesting the importance of sex-specific regression formulas for age estimation.

Amongst all the studied teeth, maxillary second premolar (for males $R^{2}=97.4$, for females $R^{2}=$ 95.3) was reported to be the most dependable marker of age due to better correlation coefficient which is supported by the previous examination done by Igbigbi et al. (Igbigbi and Nyirenda, 2005). Association of CPCI with chronological age for maxillary canine (for males $R^{2}=96.1$, for females $R^{2}$ ) was found higher than mandibular canine (for males $R^{2}=94.7$, for females $\left.R^{2}=93.1\right)$. Mandibular first premolar (for males $R^{2}=90.8$, for females 89.4) showed the least correlation with chronological age amongst all the selected teeth indicating the significance of derivation of teeth-specific age estimation equations. The maxillary teeth showed a strong correlation when contrasted with the mandibular teeth suggesting that the dentine deposition

Table 10 ANOVA of mandibular first premolar for female study samples

\begin{tabular}{lllllll}
\hline & Coefficients & $\begin{array}{l}\text { Standard } \\
\text { error }\end{array}$ & t Stat & $\begin{array}{l}P \\
\text { value }\end{array}$ & $\begin{array}{l}\text { Lower } \\
95 \%\end{array}$ & $\begin{array}{l}\text { Upper } \\
95 \%\end{array}$ \\
\hline Intercept & 64.24747 & 1.642507 & 39.1155 & $3.67 \mathrm{E}$ & 60.94839 & 67.54654 \\
& & & & -39 & & \\
$\mathrm{Cl}(\mathrm{X})$ & -0.89594 & 0.043411 & - & $4.06 \mathrm{E}$ & - & - \\
& & & 20.6385 & -26 & 0.98314 & 0.80875 \\
\hline
\end{tabular}

Table 11 Comparison between mean chronological age and mean estimated age in test subset using coronal pulp cavity index (CPCI) of maxillary canine

\begin{tabular}{lllll}
\hline Groups & $\begin{array}{l}\text { Mean } \\
\text { chronological } \\
\text { age }\end{array}$ & $\begin{array}{l}\text { Mean } \\
\text { estimated } \\
\text { age }\end{array}$ & $\begin{array}{l}\text { Mean } \\
\text { difference } \\
\text { chronological } \\
\text { age-estimated } \\
\text { age }\end{array}$ & $P$ value \\
\hline Male $(n=52)$ & 35.98 & 35.69 & 0.29 & $5.6 \mathrm{E}-37$ \\
$\begin{array}{l}\text { Female } \\
(n=52)\end{array}$ & 35.98 & 35.70 & 0.28 & $6.41 \mathrm{E}-35$ \\
\hline
\end{tabular}

may be more regular and continuous in the maxillary teeth as compared to the mandibular teeth.

Standard error varies from 0.019 (maxillary second premolar) to 0.039 (mandibular canine) (Tables 3, 4, 5 , and 6) in males and 0.020 (maxillary second premolar) to 0.043 (mandibular canine) in females (Table 7, 8, 9, and 10] which also suggests the reliability and superiority of maxillary second premolar as an age indicator over the other teeth included in the study.

Comparative analysis has been done between mean chronological age and mean estimated age in a test subset using derived linear equations. The difference between the mean chronological age and mean estimated age was found to be fluctuating from 0.27 in case of canines to 0.51 in case of the maxillary second premolar (Tables 11, 12, 13, and 14). No statistically significant difference was reported between mean estimated age and mean chronological age which is as per the results of the study conducted by Agarwal et al. (Agarwal et al. 2012). When contrasted with studies conducted by Igbigbi et al. in Malawian populations and Zadzinska et al. in Caucasian, we have observed a higher degree of accuracy in the present study featuring the significance of population-specific regression equations (Igbigbi and Nyirenda, 2005; Zadzinska et al. 2000). The differences in the results of the present study and other studies could be explained by differences in the studied popula-

Table 12 Comparison between mean chronological age and mean estimated age in test subset using coronal pulp cavity index $(\mathrm{CPCl})$ of maxillary second premolar

\begin{tabular}{lllll}
\hline Groups & $\begin{array}{l}\text { Mean } \\
\text { chronological } \\
\text { age }\end{array}$ & $\begin{array}{l}\text { Mean } \\
\text { estimated } \\
\text { age }\end{array}$ & $\begin{array}{l}\text { Mean } \\
\text { difference } \\
\text { chronological } \\
\text { age-estimated } \\
\text { age }\end{array}$ & $P$ value \\
\hline Male $(n=52)$ & 35.98 & 35.47 & 0.51 & $3.68 \mathrm{E}-41$ \\
$\begin{array}{l}\text { Female } \\
(n=52)\end{array}$ & 35.98 & 35.54 & 0.44 & $9.99 \mathrm{E}-41$ \\
\hline
\end{tabular}


Table 13 Comparison between mean chronological age and mean estimated age in test subset using coronal pulp cavity index $(\mathrm{CPCl})$ of mandibular canine

\begin{tabular}{lllll}
\hline Groups & $\begin{array}{l}\text { Mean } \\
\text { chronological } \\
\text { age }\end{array}$ & $\begin{array}{l}\text { Mean } \\
\text { estimated } \\
\text { age }\end{array}$ & $\begin{array}{l}\text { Mean } \\
\text { difference } \\
\text { chronological } \\
\text { age- } \\
\text { estimated age }\end{array}$ & $P$ value \\
\hline Male $(n=52)$ & 35.98 & 35.63 & 0.35 & $1.2 \mathrm{E}-33$ \\
Female $(n=52)$ & 35.98 & 35.61 & 0.37 & $7.95 \mathrm{E}-31$ \\
\hline
\end{tabular}

tion, difference in sample size, and type of teeth examined in the study. This method was considered to be a good predictor of age in living individuals, but further studies are required to develop more customized regression formulas for each tooth.

\section{Conclusion}

The study could be concluded that among all the studied teeth, maxillary second premolar was observed to be the best indicator of age estimation. This highlights the importance of tooth-specific linear equations for age estimation. A highly significant correlation of age with CPCI was reported in Haryana population. Although a lot of research had been done in the area of age estimation, these studies were conducted in different populations, hampering comparisons of their accuracy. To achieve more accurate age estimation, there is a need for a corroborative population-specific study with larger samples of varying age groups to investigate several teeth together like incisors, canines, premolars, molars, and multiple regression analysis considering distinctive ecological factors such as dietary habits, genetic background, and history of any illness that can affect the accuracy of results. Development of these population-specific age estimation tools may prove valuable to forensic odontologists and anthropologists in various civil and criminal cases.

Table 14 Comparison between mean chronological age and mean estimated age in test subset using coronal pulp cavity index (CPCI) of mandibular first premolar

\begin{tabular}{lllll}
\hline Groups & $\begin{array}{l}\text { Mean } \\
\text { chronological } \\
\text { age }\end{array}$ & $\begin{array}{l}\text { Mean } \\
\text { estimated } \\
\text { age }\end{array}$ & $\begin{array}{l}\text { Mean } \\
\text { difference } \\
\text { chronological } \\
\text { age- } \\
\text { estimated } \\
\text { age }\end{array}$ & $P$ value \\
\hline Male $(n=52)$ & 35.98 & 35.48 & 0.50 & $1.44 \mathrm{E}-27$ \\
Female $(n=52)$ & 35.98 & 35.57 & 0.41 & $4.06 \mathrm{E}-2$ \\
\hline
\end{tabular}

\section{Abbreviations}

$\mathrm{CH}$ : Crown height; CPCl: Coronal pulp cavity index; $\mathrm{CPH}$ : Coronal pulp height; RVG: Radiovisiographs

\section{Acknowledgements \\ The author is extremely thankful to the Dr. S. C Narula, Head \& Prof., Department of Periodontics, PGIDS, Rohtak, and Dr. Mandeep Singh Virdi, Principal, PDM Dental College and Research Institute, Bahadurgarh, for allowing me for data collection. My sincere thanks to Dr. Cheena Singh, Assistant Professor, Department of Oral medicine and Radiology, PDIGS, Rohtak, for her assistance. We are deeply indebted to all the people who have participated in this by providing their radiovisiographs (RVG) for this study.}

\section{Authors' contributions}

KS structured the conceptualized study and contributed significantly in carrying out the experiment data interpretation and manuscript preparation. KS also contributed towards designing and carrying out of experiments and in manuscript preparation. PS carried out the data analyses. VK and NS equally conceptualized the study and provided critical and valuable technical advisory content for accomplishment of the work and data processing. All authors read and approved the final manuscript.

\section{Authors' information \\ Kusum Singal and Vikas Kumar are working as Senior Research Fellows, Department of Genetics, MDU, Rohtak. \\ Dr. Neelkamal Sharma is currently working as an Assistant Professor, \\ Department of Genetics, MDU, Rohtak. \\ Dr. Permila Singh is currently working as an Assistant Professor, Department of Statistics, G.C.W, Rohtak.}

\section{Funding}

The financial support provided by UGC, New Delhi, in the form of "UGC-JRF Fellowship" (Letter No F.15-9 (JUNE 2014)/2014(NET), helped the author in preparation of this research article.

\section{Availability of data and materials}

Data sharing is not applicable to this article as no datasets were generated or analyzed during the current study.

Ethics approval and consent to participate

The protocol of the study was approved by the Institutional Human Ethical Committee, MDU Rohtak (ethical clearance dated on July 4, 2017).

\section{Consent for publication}

Not required as the manuscript does not contain any individual person's data in any form.

\section{Competing interests}

The authors declare that they have no competing interests.

\section{Author details}

'Department of Genetics, MDU Rohtak, Rohtak, India. ${ }^{2}$ Department of Statistics, G.C.W, Rohtak, India.

Received: 21 May 2018 Accepted: 14 July 2019

Published online: 25 July 2019

\section{References}

Agarwal N, Ahuja P, Sinha A, Singh A (2012) Age estimation using maxillary central incisors: a radiographic study. J Forensic Dent Sci 4:97-100

Babshet M, Acharya AB, Naikmasur VG (2010) Age estimation in Indians from pulp/ tooth area ratio of mandibular canines. Forensic Sci Int 197:125-129

Cheena S, Kusum S (2017) Teeth as a tool for age estimation: a mini review. J Forensic Sci \& Criminal Invest 6(3):555695. https://doi.org/10.19080/JFSCI.2017.06.555695

Das M, Nayyar AS, Punhani N, Puri H, Rohilla R, Chalapathi KV (2017) Validation of Kvaal's and Cameriere's methods of age estimation in people of Marathwada origin. CHRISMED J Health Res XX: XX-XX.

Drusini AG, Toso O, Ranzado C (1997) The coronal pulp cavity index: a bio marker for age determination in human adults. Am J Phys Anthropol 103:353-363 
Ferenandes M, Pereira D, Braganca P, Lima SH, Junior F (2011) Estimation by measurements of developing teeth: accuracy of Cameriere's method on a Brazilian sample. J Forensic Sci 56:1616-1619

Ge ZP, Ma RH, Li G, Zhang JZ, Ma CX (2015) Age estimation based on pulp chamber volume of first molars from cone-beam computed tomography images. Forensic Sci Int 253(133):e1-e7

Ge ZP, Yang P, Li G, Zhang JZ, Ma XC (2016) Age estimation based on pulp cavity/chamber volume of 13 types of tooth from cone beam computed tomography images. Int J Legal Med 130(4):1159-1167

Godge P, Shubhra S, Vibhakar P, Kulkarni A, Shroff, J (2014) Age estimation using orthopantomographs-a forensic study. ljocr, 2(6):26-30

Igbigbi PS, Nyirenda SK (2005) Age estimation of Malawian adults from dental radiographs. WAJM 24(4):329-333

Ikeda N, Umetsu K, Kashimura S, Suzuki T, Oumi M (1985) Estimation of age from teeth with their soft X-ray findings. JPN J For Med 39:244-250

Jagannathan N, Neelakantan P, Thiruvengadam C, Ramani P, Premkumar P, Natesan A (2011) Age estimation in an Indian population using pulp/tooth volume ratio of mandibular canines obtained from cone beam computed tomography. J Forensic Odontostomatol 29:1-6

Joseph CC, Reddy BHS, Cherian NM, Kannan SK, George G et al (2013) Intraoral dental radiography for adult age estimation: a reliable technique. J Indian Academy Oral Medi Radiol 25:287-290

Karkhanis S, Mack P, Franklin D (2013) Age estimation standards for a Western Australian population using the coronal pulp cavity index. Forensic Sci Int 231(1-3):412 e1-412 e6

Koranne W, Mhapuskar AA, Marathe SP, Joshi SA, Saddiwal RS, Nisa SU (2017) Age estimation in Indian adults by the coronal pulp cavity index. J Forensic Dent Sci 9:177

Lewis JM, Senn DR (2010) Dental age estimation utilizing third molar development: a review of principles, methods, and population studies used in the United States. Forensic Sci. Int (3):79-83

Mathew DG, Rajesh S, Koshi E, Priya LE, Nair AS, Mohan A (2013) Adult forensic age estimation using mandibular first molar radiographs: a novel technique. J Forensic Dent Sci 5:56-59

Paewinsky E, Pfeiffer H, Brinkmann B (2005) Quantification of secondary dentine formation from orthopantomograms--a contribution to forensic age estimation methods in adults. Int J Legal Med 119:27-30

Panchbhai AS (2011) Dental radiographic indicators, a key to age estimation. DentomaxillofacRadiol 40:199-212

Porto LV, Celestino da Silva Neto J, Anjos Pontual AD, Catunda RQ (2015) Evaluation of volumetric changes of teeth in a Brazilian population by using cone beam computed tomography. J Forensic Leg Med 36:4-9

Pushpa, Vaishali Keluskar, Anjana Bagewadi, Alka Kale (2017) Comparison of accuracy in age estimation by modified Kvaal's formula and coronal pulp cavity index-a radiographic study. Int. J. Adv. Res. 5(11), 1503-1510.

Rai B, Kaur J, Cingolani M, Ferrante L, Cameriere R (2010) Age estimation in children by measurement of open apices in teeth: an Indian formula. Int J Legal Med 124:237-241

Shrestha I (2014) Comparative evaluation of two established age estimation techniques (two histological and radiological) by image analysis software using single tooth. Forensic Res 5:1-6

Singal K (2017) Tooth coronal index: one of the simplest radiographic method for age estimation. Paper presentation. Annual conference cum CME of IndoPacific Association of Forensic Odontology, Chandigarh

Singal K, Sharma N (2017) Dental radiology: an adjunctive aid in age estimation. Annals and Essences of Dentistry 9(3):8c-11c

Singaraju S, Sharada P (2009) Age estimation using pulp/tooth area ratio: a digital image analysis. J Forensic Dent Sci 1:37-41

Stavrianos CH, Mastagas D, Stavrianou I, Karaiskou O (2008) Dental age estimation of adults: a review of methods and principles. Res J Med Sci 2:258-268

Takasaki T, Tsuji A, lkeda N, Ohishi M (2003) Age estimation in dental pulp DNA based on human telomere shortening. Int I Legal Med 117:232-234

Talabani RM, Baban MT, Mahmood MA (2015) Age estimation using lower permanent first molars on a panoramic radiograph: a digital image analysis. J Forensic Dent Sci 7:158-162

Zadzinska E, Drusini AG, Carrara N (2000) The comparison between two age estimation methods based on human teeth. Anthropol Rev 63:95-101

\section{Publisher's Note}

Springer Nature remains neutral with regard to jurisdictional claims in published maps and institutional affiliations.

\section{Submit your manuscript to a SpringerOpen ${ }^{\circ}$ journal and benefit from:}

- Convenient online submission

- Rigorous peer review

- Open access: articles freely available online

- High visibility within the field

- Retaining the copyright to your article

Submit your next manuscript at $\boldsymbol{\nabla}$ springeropen.com 